\title{
The flavonoid galangin is an inhibitor of CYP1A1 activity and an agonist/antagonist of the aryl hydrocarbon receptor
}

\section{HP Ciolino and GC Yeh}

Cellular Defense and Carcinogenesis Section, Basic Research Laboratory, Division of Basic Sciences, National Cancer Institute-Frederick Cancer Research and Development Center, NIH, Frederick, MD 21702-1201, USA

Summary The effect of the dietary flavonoid galangin on the metabolism of 7,12-dimethylbenz[a]anthracene (DMBA), the activity of cytochrome $\mathrm{P}_{450} 1 \mathrm{~A} 1$ (CYP1A1), and the expression of CYP1A1 in MCF-7 human breast carcinoma cells was investigated. Galangin inhibited the catabolic breakdown of DMBA, as measured by thin-layer chromatography, in a dose-dependent manner. Galangin also inhibited the formation of DMBA-DNA adducts, and prevented DMBA-induced inhibition of cell growth. Galangin caused a potent, dose-dependent inhibition of CYP1A1 activity, as measured by ethoxyresorufin-O-deethylase activity, in intact cells and in microsomes isolated from DMBAtreated cells. Analysis of the inhibition kinetics by double-reciprocal plot demonstrated that galangin inhibited CYP1A1 activity in a noncompetitive manner. Galangin caused an increase in the level of CYP1A1 mRNA, indicating that it may be an agonist of the aryl hydrocarbon receptor, but it inhibited the induction of CYP1A1 mRNA by DMBA or by 2,3,5,7-tetrachlorodibenzo-p-dioxin (TCDD). Galangin also inhibited the DMBA- or TCDD-induced transcription of a reporter vector containing the CYP1A1 promoter. Thus, galangin is a potent inhibitor of DMBA metabolism and an agonist/antagonist of the AhR, and may prove to be an effective chemopreventive agent.

Keywords: galangin; flavonoid; DMBA; CYP1A1; EROD

Numerous epidemiological studies have demonstrated that diets rich in fruits and vegetables are protective against several forms of cancer (Steinmetz and Potter, 1996), and much attention has been focused on whether naturally occurring dietary components can modify the mutagenic and carcinogenic effects of environmental carcinogens. 7,12-dimethylbenz $[a]$ anthracene (DMBA), a model compound which induces mammary tumorigenesis in rodents (Huggins et al, 1961), is a member of one such class of carcinogen, the aryl hydrocarbons. Aryl hydrocarbons bind and activate the aryl hydrocarbon receptor (AhR), which induces the transcription of a number of genes (Rowlands and Gustafsson, 1997), including the cytochrome $\mathrm{P}_{450} 1 \mathrm{~A}$ (CYP1A) enzyme family. CYP1As mediate the oxidative catabolism of aryl hydrocarbons, generating genotoxic metabolites which can bind specific residues of DNA, introducing mutations in key genes and resulting in cellular transformation (Dipple, 1995). Inhibition of the metabolic activation of carcinogens, either through inhibition of the AhR-mediated signal transduction pathway or direct enzyme inhibition, is believed to be an important mechanism in chemoprevention.

Flavonoids are among the most abundant of phytochemicals and much attention has been focused recently on the effect of flavonoids on chemically induced in vivo models of carcinogenesis. Flavonoids consist of a diverse group of polyphenolic derivatives of benzo- $\gamma$-pyrone that are ubiquitous in foods of plant origin such as vegetables, fruit, tea and wine (Formica and Regelson,

Received 26 May 1998

Revised 16 September 1998

Accepted 22 September 1998

Correspondence to: HP Ciolino, BRL, NCI-FCRDC, Building 560/Rm 12-05, PO Box B, Frederick, MD 21702-1201, USA
1995). Dietary intake of flavonoids has been estimated at $1 \mathrm{~g}$ per day (Kuhnau, 1976), but recent studies have indicated that consumption varies widely (Hollman and Katan, 1997; Hollman et al, 1997). In vivo studies have shown that some flavonoids are effective in preventing chemically induced cancer in rodents, including DMBA-induced mammary cancer (Verma et al, 1988; Lamartiniere et al, 1995). Flavonoids exert a multiplicity of biochemical actions that are believed to be an important part of the chemopreventive effect of plant-based diets. Various flavonoids are potent antioxidants (Kono et al, 1997; Noda et al, 1997), inhibit lipoxygenase and cyclooxygenase (Mirzoeva and Calder, 1996), affect the activity of several hepatic enzymes involved in activation and detoxification of carcinogens (Canivenc-Lavier et al, 1996), inhibit cellular proliferation (Tsyrlov et al, 1994; Siess et al, 1995; Moon et al, 1998), and induce apoptosis of tumour cells (Csokay et al, 1997). Galangin, a member of the flavonol class of flavonoids, is present in high concentrations in Alpina officinarum (common name: China or India root), which has been used as a spice and as a herbal medicine for a variety of ailments in Asia for centuries. Galangin has been shown to inhibit the proliferation of breast tumour cells (So et al, 1996, 1997), and to inhibit the cytochrome $\mathrm{P}_{450}$-dependent hydroxylation of the aryl hydrocarbon benzo[a]pyrene in human liver microsomes (Buening et al, 1981).

For this report we have examined the effects of galangin on the carcinogen activation pathway mediated by the AhR. We have used the MCF-7 human breast carcinoma cell line because it is derived from the target tissue of DMBA, the mammary epithelium, and because AhR function and carcinogen activation has been well characterized in these cells (Christou et al, 1994; Moore et al, 1994; Dohr et al, 1995; Wang et al, 1995). Furthermore, a recent study has demonstrated that MCF-7 cells are similar to normal human mammary epithelial cells with regard to AhR 
expression and CYP1A1 activity (Larson et al, 1998). We demonstrate that galangin inhibits the activation of DMBA by inhibiting AhR function and CYP1A1 enzyme activity, and thus may be a promising candidate for in vivo chemoprevention study.

\section{MATERIALS AND METHODS}

\section{Materials}

Except as noted, all chemicals were from Sigma (St Louis, MO, USA). All culture vessels were from CoStar (Cambridge, MA, USA). Galangin (Aldrich, Milwaukee, WI, USA) was dissolved in dimethylsulphoxide (DMSO) and stored at $-20^{\circ} \mathrm{C}$.

\section{Cell culture}

MCF-7 cells (American Type Culture Collection, Rockville, MD, USA) were grown in RPMI-1640 supplemented with 2 mM glutamine and $10 \%$ fetal bovine serum (all from BioFluids, Rockville, MD, USA). Cells were sub-cultured weekly using $0.25 \%$ trypsin $/ 0.05 \%$ EDTA (BioFluids). All experiments were carried out at $37^{\circ} \mathrm{C}$ and $5 \%$ carbon dioxide on confluent cells in growth medium, except where indicated.

\section{Measurement of DMBA metabolism}

All steps were carried out in the dark or under yellow light. MCF-7 cells in $175 \mathrm{~cm}^{2}$ flasks were incubated in $12 \mathrm{ml}$ of growth medium containing $0.1 \mu \mathrm{g} \quad \mathrm{ml}^{-1} \quad\left[{ }^{3} \mathrm{H}\right] \mathrm{DMBA}$ (Amersham, Arlington Heights, IL, USA) in the presence of DMSO (control), $1 \mu \mathrm{M}$, or $10 \mu \mathrm{M}$ galangin. After $24 \mathrm{~h}, 1 \mathrm{ml}$ of the medium was removed and extracted with $1 \mathrm{ml}$ ethyl acetate. $\left[{ }^{3} \mathrm{H}\right] \mathrm{DMBA}$ was separated from metabolites by thin-layer chromatography. A total of $5 \mu \mathrm{l}$ of the organic phase was applied to a $20 \times 20 \mathrm{~cm}^{2}$ silica thin-layer chromatography sheet with fluorescent indicator (Kodak, Rochester, NY, USA). Chromatography was performed in n-hexane for $80 \mathrm{~min}$. The sheet was dried and $121.7-\mathrm{cm}$ strips were cut, placed in $20 \mathrm{ml}$ BSC-NA organic scintillation fluid (Amersham) and counted. The parent compound migrated to the seventh and eighth strips while the metabolites migrated to the first two strips (counted from the point of application). Spontaneous decomposition of [ $\left.{ }^{3} \mathrm{H}\right] \mathrm{DMBA}$ was determined by incubating flasks without cells under the same conditions. The amount of metabolites formed in blank flasks $(20 \pm 0.58 \% ; n=3)$ was subtracted from the other incubations.

\section{Measurement of DMBA-DNA adduct formation}

Confluent cultures of MCF-7 cells in $75 \mathrm{~cm}^{2}$ flasks were exposed to $0.1 \mu \mathrm{g} \mathrm{ml}^{-1}\left[{ }^{3} \mathrm{H}\right] \mathrm{DMBA}$ in the presence of the indicated concentrations of galangin for $8 \mathrm{~h}$. Cells were washed twice with cold phosphate-buffered saline (PBS), trypsinized and pelleted. Nuclei were isolated by incubating the cells for $10 \mathrm{~min}$ on ice in $10 \mathrm{mM}$ Tris-HCl, pH 7.5, with $320 \mathrm{~mm}$ sucrose, $5.0 \mathrm{~mm}$ magnesium chloride and $1 \%$ Triton $\mathrm{X}-100$. The nuclei were pelleted by centrifugation at $800 \mathrm{~g}$ for $10 \mathrm{~min}$ at $4^{\circ} \mathrm{C}$, and this digestion was repeated once. Nuclei were then lysed with $1 \%$ sodium dodecyl sulphate (SDS) in $0.5 \mathrm{~m}$ Tris, $20 \mathrm{~mm}$ EDTA and $10 \mathrm{~mm} \mathrm{NaCl}, \mathrm{pH} 9.0$, followed by treatment with $20 \mathrm{mg} \mathrm{ml}^{-1}$ proteinase $\mathrm{K}$ for $6 \mathrm{~h}$ at $48^{\circ} \mathrm{C}$. Protein and peptides were precipitated by the addition of
$\mathrm{NaCl}$ to final concentration of $1 \mathrm{M}$ and centrifuged at $500 \mathrm{~g}$ for 30 min at $4{ }^{\circ} \mathrm{C}$. Genomic DNA was then isolated from supernatant by repeated ethanol precipitation as described in Miller et al (1988). DNA isolated by this method exhibited a 260/280 ratio of $>1.9$. The amount of DNA was measured by spectrophotometry and the adducts were quantified by liquid scintillation counting in Ecoscint A (National Diagnostics, Atlanta, GA, USA).

\section{Measurement of cell growth}

MCF-7 cells were plated out in 24-well plates at 25000 cell per well and allowed to attach for $24 \mathrm{~h}$. DMBA was added at the indicated concentrations with either DMSO (control) or $5.0 \mu \mathrm{M}$ galangin in fresh media. Total cell growth was assayed after 3 days using sulphorhodamine (Rubinstein et al, 1990).

\section{CYP1A1 activity in intact MCF-7 cells}

MCF-7 cells in 24-well plates were treated with $1 \mathrm{ml}$ growth medium containing $1 \mu \mathrm{M}$ DMBA for $24 \mathrm{~h}$ in the presence of DMSO or the indicated concentrations of galangin. At the end of the incubation, the medium was removed and the wells were washed two times with fresh medium. Ethoxyresorufin- $O$-deethylase (EROD) activity, which is a specific assay of the bioactivation capacity of CYP1A1, was determined in intact cells as described in Kennedy and Jones (1994) using $5 \mu \mathrm{M}$ ethoxyresorufin (ETRF) in growth medium as a substrate in the presence of $1.5 \mathrm{~mm}$ salicylamide to inhibit conjugating enzymes (Lubinski et al, 1994). The assay was carried out at $37^{\circ} \mathrm{C}$. The fluorescence of resorufin generated by the conversion of ETRF by CYP1A1 was measured every $10 \mathrm{~min}$ for $60 \mathrm{~min}$ in a CytoFlor II multiwell fluorescence plate reader (PerSeptive Biosystems, Framingham, MA, USA), with an excitation of $530 \mathrm{~nm}$ and emission at $590 \mathrm{~nm}$.

\section{Microsomal CYP1A1 activity}

MCF-7 cells were treated with $1 \mu \mathrm{M}$ DMBA for $24 \mathrm{~h}$ to induce CYP1A1 EROD activity. Microsomes were isolated as follows: the cells were washed once with PBS, trypsinized and pelleted by centrifugation at $800 \mathrm{~g}$ for $10 \mathrm{~min}$ at $4^{\circ} \mathrm{C}$. The pellet was washed in PBS, repelleted, then resuspended in $0.25 \mathrm{M}$ sucrose, $10 \mathrm{~mm}$ Tris$\mathrm{HCl}, \mathrm{pH} 7.5$, with protease inhibitors $\left(100 \mu \mathrm{g} \mathrm{ml}^{-1}\right.$ phenylmethylsulphonylfluoride, $300 \mu \mathrm{g} \mathrm{ml}^{-1}$ EDTA, $0.5 \mu \mathrm{g} \mathrm{ml^{-1 }}$ leupeptin, 0.5 $\mu \mathrm{g} \mathrm{ml} \mathrm{m}^{-1}$ aprotinin and $0.7 \mu \mathrm{g} \mathrm{ml}^{-1}$ Pepstatin A). The cells were sonicated for $30 \mathrm{~s}$ on ice using a Branson Sonifier at setting 2. The sonicate was centrifuged at $10000 \mathrm{~g}$ for $10 \mathrm{~min}$ at $4^{\circ} \mathrm{C}$ and the supernatant was centrifuged at $500000 \mathrm{~g}$ for $15 \mathrm{~min}$ at $4{ }^{\circ} \mathrm{C}$. The resulting microsomal pellet was resuspended in the above buffer and the protein assayed by the Bradford method (1976). Aliquots of microsomes were stored at $-80^{\circ} \mathrm{C}$. CYP1A1 activity was determined by EROD assay in the following manner: for Figure $5 \mathrm{~A}, 10 \mu \mathrm{g}$ of microsomes were brought up to $100 \mu \mathrm{l}$ with PBS, pH 7.2, 400 nM ETRF was added, along with DMSO or the indicated concentrations of galangin. The reaction was initiated by the addition of $250 \mu \mathrm{M}$ NADPH. The reaction mixture was transferred to a 96-well plate and EROD activity was determined in a Cytoflor II Fluorescence Plate Reader as described above. For Figure 5B, $250 \mu \mathrm{M}$ NADPH and 100-1600 nM ETRF were added to $3 \mathrm{ml}$ of PBS, pH 7.2, $410 \mu \mathrm{l}$ aliquots were removed to which DMSO or the indicated concentration of galangin were 


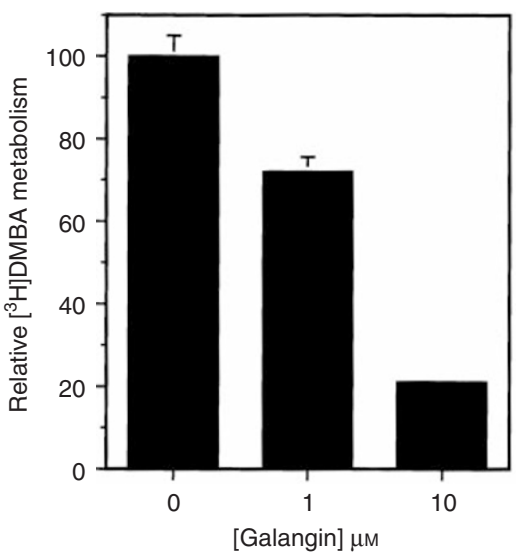

Figure 1 Effect of galangin on the metabolic catabolism of $\left[{ }^{3} \mathrm{H}\right] \mathrm{DMBA}$ MCF-7 cells were exposed to $0.1 \mu \mathrm{g} \mathrm{ml}^{-1}\left[{ }^{3} \mathrm{H}\right] \mathrm{DMBA}$ in the presence of DMSO (vehicle control), $1 \mu \mathrm{M}$, or $10 \mu \mathrm{m}$ galangin for $24 \mathrm{~h}$. $\left[{ }^{3} \mathrm{H}\right] \mathrm{DMBA}$ and metabolites were extracted and analysed by thin-layer chromatography. Each bar represents the mean of 3 determinations \pm standard error (s.e.). DMBA metabolism in cultures treated with galangin was statistically different from controls $(P<0.05)$

added. The reaction was initiated by the addition of $45 \mu \mathrm{g}$ of microsomal protein (final volume was $450 \mu \mathrm{l}$ ) and gently vortexed. Four $100-\mu 1$ aliquots $(10 \mu \mathrm{g}$ per assay) of each were removed, placed in a 96-well plate and assayed as above. A standard curve was constructed using resorufin.

\section{Reverse transcription polymerase chain reaction (RT-PCR)}

Confluent MCF-7 cells were treated with a combination of galangin and $1 \mathrm{nM}$ 2,3,7,8-tetrachlorodibenzo-p-dioxin (TCDD) or $250 \mathrm{~nm}$ DMBA for $6 \mathrm{~h}$, or with galangin alone for $24 \mathrm{~h}$. The cells were washed twice with PBS and total RNA was isolated using Trizol reagent (GibcoBRL, Gaithersburg, MD, USA). Semi-quantitative RT-PCR for CYP1A1 and glyceraldehyde-3-phosphate dehydrogenase $(\mathrm{GPDH})$ was performed in the presence of $1.5 \mu \mathrm{Ci}$ [32P]dATP (DuPont/NEN, Wilmington, DE, USA) using the primer sequences and conditions of Dohr et al (1995). cDNA was synthesized from $10 \mu \mathrm{g}$ total RNA using a Stratagene RT-PCR kit (LaJolla, CA, USA) as instructed. The optimum cycle number that fell within the exponential range of response for both CYP1A1 (23 cycles) and GPDH (19 cycles) was used. Following PCR, $5 \mu \mathrm{l}$ of high-density sample buffer was added to the samples and they were subjected to electrophoresis on a $10 \%$ Tris-borate-EDTA (TBE) gel in $1 \times$ TBE running buffer (all components from Novex, San Diego, CA, USA). The gel was dried and the results were visualized and quantified on a BioRad GS-363 Molecular Imaging System (Hercules, CA, USA). Graphs of the resulting data were generated by normalizing CYP1A1 to GPDH.

\section{CAT- $\beta$-galactosidase assays}

MCF-7 cells were plated at 60000 cells per well in 24-well plates. After $24 \mathrm{~h}$ the cells were transiently transfected with $12.0 \mu \mathrm{g}$ of a chloramphenicol acetyltransferase (CAT) reporter vector containing the full length rat CYP1Al promoter (pMC6.3K; Sogawa et al, 1986) using LipofectAmine (GibcoBRL) as directed. To control for transfection efficiency, the cells were co-transfected

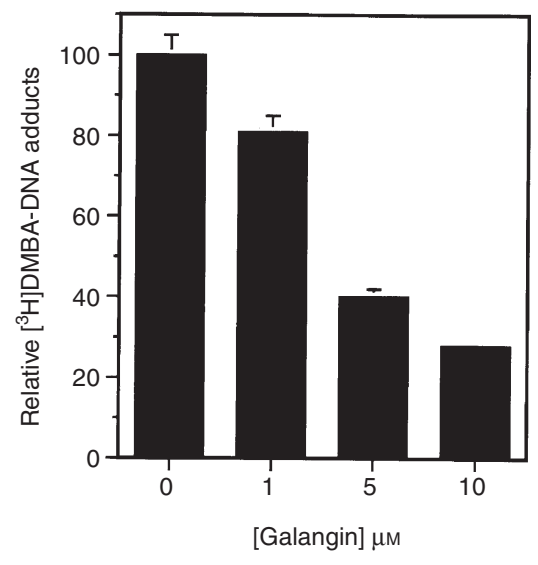

Figure 2 Effect of galangin on [ $\left.{ }^{3} \mathrm{H}\right] \mathrm{DMBA}-\mathrm{DNA}$ adduct formation. MCF-7 cells were incubated with $0.1 \mu \mathrm{g} \mathrm{ml}^{-1}\left[{ }^{3} \mathrm{H}\right] \mathrm{DMBA}$ in the presence of DMSO, or the indicated concentrations of galangin for $8 \mathrm{~h}$. DNA was extracted and analysed for incorporation of [ $\left.{ }^{3} \mathrm{H}\right] \mathrm{DMBA}$ metabolites as described. Each bar represents the mean of 4 determinations \pm s.e. Adduct formation in all galangin-treated samples was statistically different from controls $(P<0.05)$

with $1.0 \mu \mathrm{g}$ of $\mathrm{pCMZ}$ vector containing $\beta$-galactosidase (Clonetech Labs, Palo Alto, CA, USA). After a further $24 \mathrm{~h}$, the cells were treated with $1 \mathrm{nM}$ TCDD or $250 \mathrm{~nm}$ DMBA in the presence of DMSO (control) or galangin for $6 \mathrm{~h}$. The amount of CAT transcription was determined using an ELISA assay (Boehringer Mannheim, Indianapolis, IN, USA) as directed. Activity of $\beta$ galactosidase was determined by the method of Rosenthal (1987). The amount of CAT transcription was normalized to $\beta$-galactosidase transcription.

\section{Statistical analysis}

Statistical analyses were performed using StatView Statistical Analysis software (SAS Institute, San Francisco, CA, USA). Differences between group mean values were determined by a one-factor analysis of variance (ANOVA), followed by Fisher PSLD post-hoc analysis for pair wise comparison of means.

\section{RESULTS}

\section{Effect of galangin on the metabolism of $\left[{ }^{3} \mathrm{H}\right] \mathrm{DMBA}$}

MCF-7 cells were incubated with $\left[{ }^{3} \mathrm{H}\right] \mathrm{DMBA}$ in the presence or absence of galangin for $24 \mathrm{~h}$ and the catabolism of DMBA was determined by thin-layer chromatography. After $24 \mathrm{~h}, 65 \pm 2.1 \%$ $(3.1 \pm 0.1$ nmoles of DMBA per flask per $24 \mathrm{~h}$ ) of the parent compound had been converted to metabolites in untreated cells. Galangin caused a dose-dependent inhibition of $\left[{ }^{3} \mathrm{H}\right] \mathrm{DMBA}$ catabolism (Figure 1).

The effect of galangin on the formation of adducts between metabolites of DMBA and DNA in MCF-7 cells was examined. In control cultures, exposure to $0.1 \mu \mathrm{g} \mathrm{ml}{ }^{-1}\left[{ }^{3} \mathrm{H}\right] \mathrm{DMBA}$ for $8 \mathrm{~h}$ resulted in the formation of $3035 \pm 168$ fmoles adducts per mg DNA. Exposure of the cells to $\left[{ }^{3} \mathrm{H}\right] \mathrm{DMBA}$ in the presence of galangin inhibited DMBA-DNA adduct formation in a dosedependent manner (Figure 2).

We measured the growth of MCF-7 cells after 3 days of incubation with increasing concentrations of DMBA in the presence or 


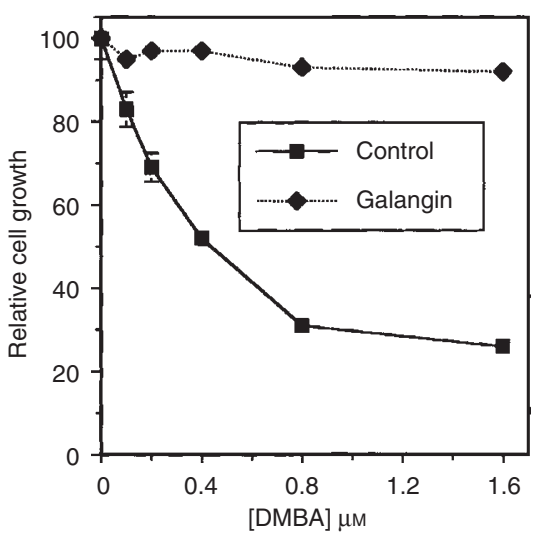

Figure 3 Effect of galangin on DMBA-induced cytotoxicity. MCF-7 cells were plated out at 25000 cells per well in 24 -well plates. After $24 \mathrm{~h}$, the medium was changed with medium containing the indicated concentrations of DMBA and DMSO (vehicle control) or $5 \mu \mathrm{M}$ galangin. After 3 days cell growth was measured with sulphorhodamine. Each point represents the mean of 4 determinations \pm s.e. Cell growth was significantly different in galangin-treated cultures beginning at $100 \mathrm{~nm}$ DMBA $(P<0.05)$

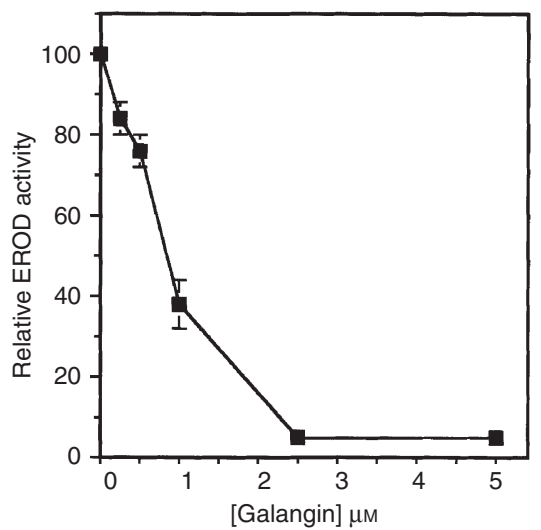

Figure 4 Effect of galangin on DMBA-induced CYP1A1 activity in intact cells. MCF-7 cells were treated with $1 \mu \mathrm{M}$ DMBA in the presence of the indicated concentrations of galangin for $24 \mathrm{~h}$. CYP1A1 activity was measured by EROD assay in intact cells as described. EROD activity in control cultures was $4.01 \pm 0.12$ pmoles per min for each well. Each point represents the mean of 4 determinations \pm s.e. EROD activity in all galangin-treated samples was statistically different from controls $(P<0.05)$

absence of $5 \mu \mathrm{M}$ galangin. Galangin completely inhibited DMBAinduced cytotoxicity at the concentrations tested (Figure 3). Galangin at the tested concentration had no effect on cell growth by itself (data not shown).

\section{Effect of galangin on CYP1A1 activity}

We measured the activity of CYP1A1 using the EROD assay, which is specific for the CYP1A1 enzyme family. There was no EROD activity in MCF-7 cells in the absence of DMBA treatment. Treatment of cells with DMBA caused a dose-dependent increase in EROD activity (data not shown). We measured the EROD activity in intact cells which had been exposed to $1 \mu \mathrm{M}$ DMBA in the presence of galangin. Galangin caused a dose-dependent inhibition of EROD activity with an $\mathrm{IC}_{50}$ of less than $1 \mu \mathrm{M}$ (Figure 4).

The EROD activity in microsomes isolated from cells treated with $1 \mu \mathrm{M}$ DMBA was potently inhibited by galangin in a dose-dependent

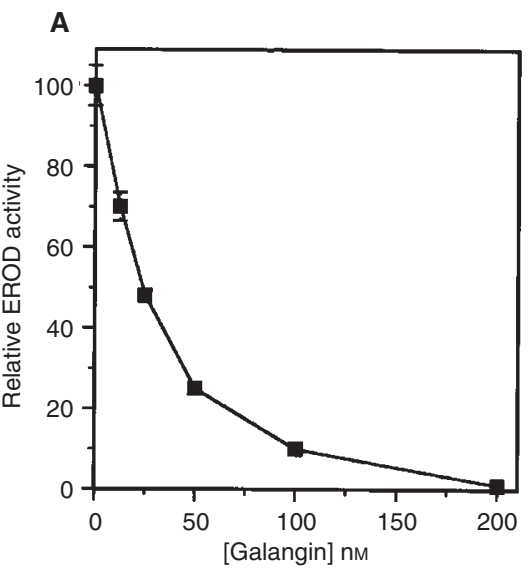

B

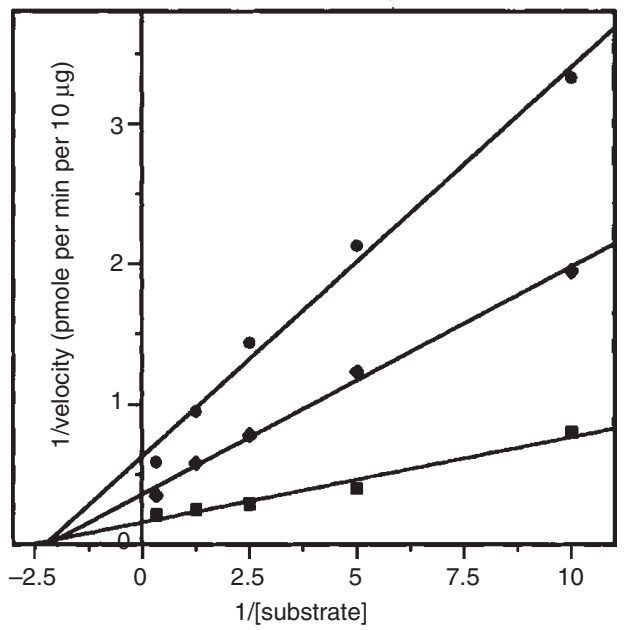

Figure 5 Effect of galangin on microsomal CYP1A1 activity. Microsomes were isolated from MCF-7 cells treated with $1 \mu \mathrm{M}$ DMBA. (A) The CYP1A1 activity in $10 \mu \mathrm{g}$ of microsomes was measured by EROD assay in the presence of $400 \mathrm{~nm}$ ETRF and the indicated concentrations of galangin. Each point represents the average of 4 determinations \pm s.e. EROD activity in controls was $2.33 \pm 0.1$ pmoles per min per $10 \mu \mathrm{g}$. EROD activity in all galangin-treated samples was statistically different from controls $(P<0.05)$. (B) EROD activity in $10 \mu \mathrm{g}$ of microsomes was measured in the presence of $0(\square), 25(\diamond)$, or $50 \mathrm{~nm}(\bigcirc)$ galangin and 100-1600 nм ETRF and a doublereciprocal (Lineweaver-Burk) plot was generated. Each point represents the mean of 4 determinations

manner, with an $\mathrm{IC}_{50}$ of approximately $30 \mathrm{nM}$ (Figure 5A). Microsomal EROD activity with or without galangin was also measured in the presence of different substrate concentration and the kinetics of enzyme inhibition by galangin were analysed by double-reciprocal (Lineweaver-Burk) analysis (Figure 5B). The $V_{\max }$ of the enzyme shifted from 5.55 pmoles per min per $10 \mu \mathrm{g}$ microsomes in the absence of galangin to 2.56 or 1.67 pmoles per min per $10 \mu \mathrm{g}$ in the presence of 25 or $50 \mathrm{nM}$ galangin, while the $K_{\mathrm{m}}$ remained unchanged, indicating a non-competitive type of inhibition.

\section{Effect of galangin on CYP1A1 expression}

Treatment of MCF-7 cells with $1 \mathrm{nM}$ of the known AhR ligand TCDD for $6 \mathrm{~h}$ resulted in a 40-fold increase in CYP1A1 mRNA compared to DMSO control, as determined by semi-quantitative RT-PCR. This increase was inhibited by galangin in a dosedependent manner (Figure 6A). Treatment of the cells with $250 \mathrm{nM}$ 
A TCDD

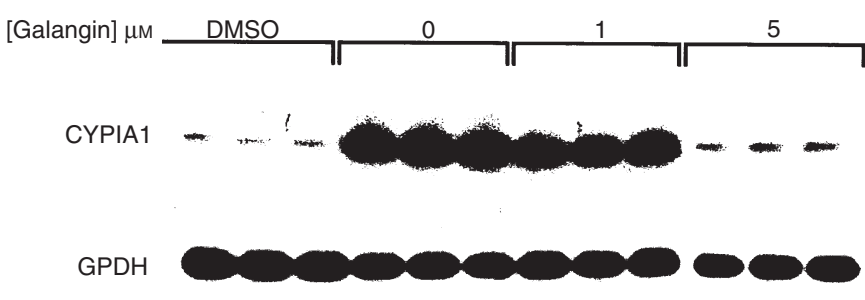

B DMBA

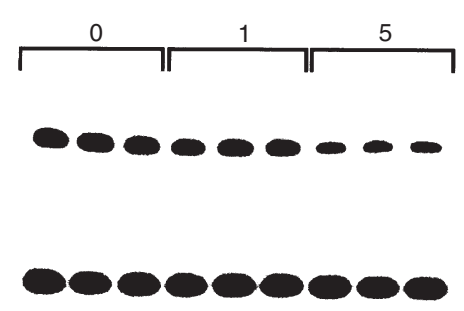

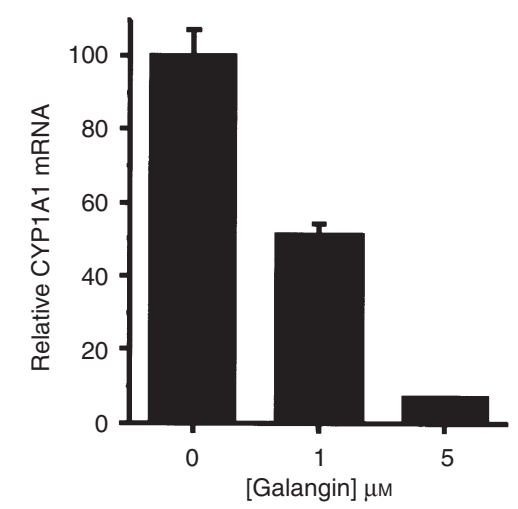

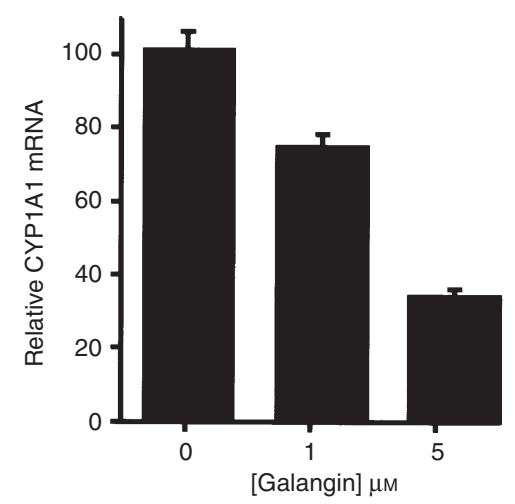

Figure 6 Effect of galangin on the induction of CYP1A1 mRNA by TCDD or DMBA. MCF-7 cells were treated with $10 \mathrm{~nm}$ TCDD or $250 \mathrm{~nm}$ DMBA in the presence of the indicated concentrations of galangin for $6 \mathrm{~h}$. Control was treated with DMSO only. RT-PCR was performed, the product was subjected to electrophoresis, and the gel was analysed and quantified with a phosphoimager. For graph, CYP1A1 mRNA was normalized to GPDH mRNA. $n=3 \pm$ s.e. The level of CYP1A1 mRNA in all galangin-treated samples was statistically different from the TCDD- or DMBA-treated cultures $(P<0.05)$

DMBA resulted in a tenfold increase in CYP1A1 mRNA, which was also inhibited by galangin (Figure 6B).

The effect of galangin on the transcription of a CAT reporter vector controlled by the CYPIAl promoter was determined by transient transfection studies. Treatment of transfected cells for $6 \mathrm{~h}$ with $1 \mathrm{nM}$ TCDD caused a sevenfold increase in CAT transcription. This was inhibited in the presence of galangin in a dosedependent manner (Figure 7). DMBA at $250 \mathrm{nM}$ induced a threefold increase in transcription that was also inhibited by galangin.

Treatment of MCF-7 cells with galangin alone for $24 \mathrm{~h}$ resulted in a dose-dependent increase in CYP1A1 mRNA (Figure 8). This increase was blocked by the RNA polymerase inhibitor actinomycin $\mathrm{D}$, indicating that the increase in mRNA was the result of transcriptional activation (data not shown).

\section{DISCUSSION}

Current cancer prevention strategy is based on the growing awareness of the powerful anti-carcinogenic activities of plant-based diets. The central tenet of this strategy is that minor dietary constituents inhibit carcinogenesis through different mechanisms of action. The steps between exposure to a procarcinogen and the transformation of a normal cell to a cancer cell begin with the activation of the procarcinogen by cytochrome $\mathrm{P}_{450}$ enzyme(s). This generates metabolites which may be converted to easily excreted forms by Phase II enzymes, but also generates epoxides which are highly electrophilic and carcinogenic, capable of reacting with DNA and causing mutations. One mechanism of action of the so-called 'blocking' type of chemopreventive agent, as classified by Wattenburg (1985), is the inhibition of the procarcinogen activation step. In the present study we have investigated the effect of the dietary flavonoid galangin on the carcinogen activation pathway mediated by the AhR. Galangin is of particular interest because its effects on other in vitro mechanisms relevant to chemoprevention has been extensively studied (Critchfield et al, 1994; Eaton et al, 1996; Kao et al, 1998), but there is, to our knowledge, no study which has examined its effect on the AhR and the pathway it regulates.

We assessed the effect of galangin on the activation of DMBA. Galangin inhibited the catabolic breakdown of DMBA (Figure 1). Since the parent compound does not react with DNA, we hypothesized that galangin would decrease DMBA-DNA adduct formation, which proved true (Figure 2). In the tissue culture setting, DMBA inhibits cell growth because of DNA adduct formation. We reasoned that decreased adduct formation would therefore reduce the cytotoxicity of DMBA in vitro. In fact, at the concentration tested, galangin completely abolished the cytotoxic effect of DMBA (Figure 3). Galangin itself was not cytotoxic at the tested concentration. These experiments indicate that galangin inhibits the activation of DMBA to genotoxic metabolites. There is, to our knowledge, no study assessing the physiologically relevant concentrations that galangin may achieve, but other flavonoids have been measured in the plasma and some tissues of humans in the range of concentrations used in this study (Morton et al, 1997; Hollman and Katan, 1998). Moreover, these concentrations correspond to plasma concentrations found in rats fed with a flavonoidenriched diet (Manach et al, 1995). 


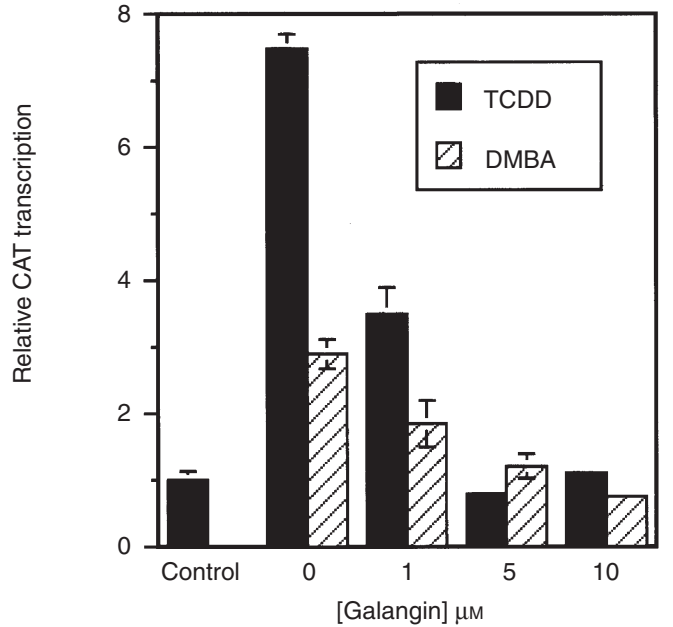

Figure 7 Effect of galangin on TCDD- or DMBA-induced CAT transcription. MCF-7 cells were transfected with an aryl hydrocarbon-responsive CAT reporter vector containing the full length CYP1A1 promoter and a $\beta$ galactosidase vector as described in Materials and Methods. Cells were treated with $1 \mathrm{~nm}$ TCDD or $250 \mathrm{~nm}$ DMBA for $6 \mathrm{~h}$ in the presence of DMSO (control) or the indicated concentrations of galangin. The amount of CAT transcription was normalized to the amount of $\beta$-galactosidase transcription. $n=4 \pm$ s.e. The amount of CAT transcription in galangin-treated cultures was statistically different from TCDD- or DMBA-treated cultures $(P<0.05)$

We next examined the mechanism(s) of galangin's action. The activity of CYP1A1 was measured by EROD assay, a specific indicator of the CYP1A1 bioactivation capabilities. Under conditions of AhR activation, the major DMBA activating isozyme in MCF-7 cells is CYP1A1 (Christou et al, 1994). These cells also express CYP1B1, but it is unclear whether this isozyme can metabolize DMBA (Shimada et al, 1997), or whether CYP1B1 possess significant EROD activity (Dohr et al, 1995; Shimada et al, 1997). Co-treatment of the cells with DMBA and increasing concentrations of galangin resulted in a dose-dependent inhibition of DMBA-induced EROD activity in intact cells (Figure 4). We could not determine, from this experiment, whether galangin's effect was as a result of inhibition at the enzyme level or through a disruption of the signal transduction pathway leading to the transcriptional activation of the CYPIAl gene. We therefore performed EROD assays on microsomes isolated from DMBAtreated cells. Galangin proved to be a potent inhibitor of microsomal EROD activity (Figure 5A). Previous studies have shown that the related flavonol quercetin inhibits EROD activity in rat hepatic microsomes in a competitive fashion (Sousa and Marletta, 1985), a result we confirmed in MCF-7 microsomes (data not shown). Analysis of the kinetics of inhibition by galangin, however, revealed that galangin inhibits EROD activity in a noncompetitive manner (Figure 5B). Thus, the interaction of galangin with CYP1A1 is different than the structurally similar quercetin.

DMBA causes the transcriptional activation of the CYP1A1 gene through the AhR. Although the results of the microsomal EROD assays indicate that direct enzyme inhibition by galangin can account for the decrease in DMBA-induced EROD activity in intact cells, we also tested the hypothesis that galangin may disrupt the transciptional activation of CYP1A1. When MCF-7 cells were treated with $250 \mathrm{nM}$ DMBA for $6 \mathrm{~h}$, there was an approximately tenfold increase in CYP1A1 mRNA compared to DMSO control. Co-treatment with galangin caused a dose-dependent inhibition of the DMBA-induced increase in CYP1A1 mRNA (Figure 6B).

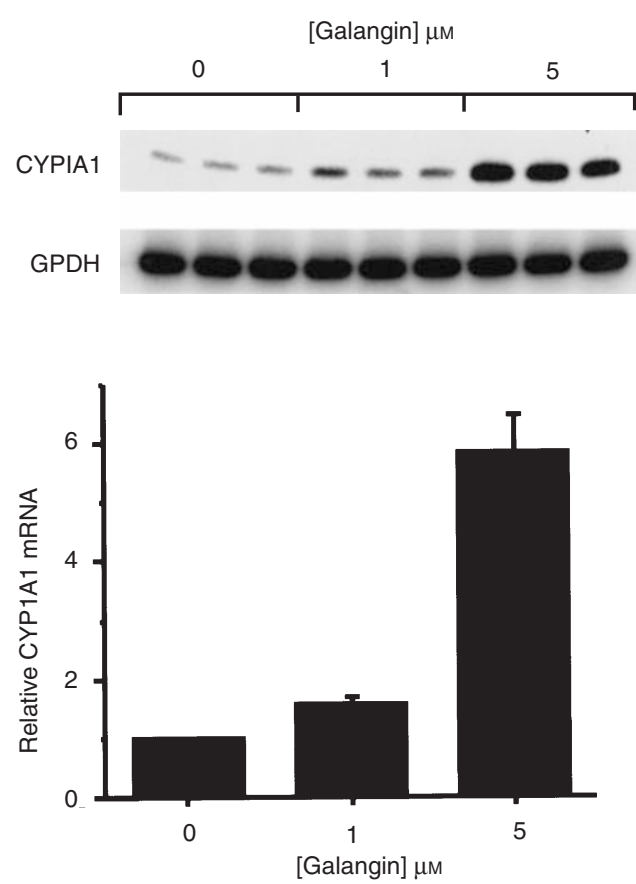

Figure 8 Effect of galangin on CYP1A1 mRNA. MCF-7 cells were treated with the indicated concentrations of galangin for $24 \mathrm{~h}$. For graph, CYP1A1 mRNA was normalized to GPDH mRNA \pm s.e. The amount of CYP1A1 mRNA was statistically significant from controls in cultures treated with $5 \mu \mathrm{m}$, but not $1 \mu \mathrm{M}$, galangin

Galangin also inhibited the increase in CYP1A1 mRNA by the prototypical AhR ligand TCDD (Figure 6A). Galangin also inhibited the DMBA- or TCDD-induced transcription of CAT in a reporter vector controlled by the $C Y P 1 A 1$ promoter (Figure 7). We also observed that treatment of the cells with galangin alone for a longer period of time $(24 \mathrm{~h})$ could induce a mild increase (compared to DMBA or TCDD) in CYP1A1 mRNA (Figure 8). This increase was blocked by the RNA polymerase inhibitor actinomycin D, which prevents de novo RNA synthesis resulting from transcriptional activation (data not shown). These results are consistent with the hypothesis that galangin is a weak ligand of the $\mathrm{AhR}$ and is able to compete for the AhR with traditional activators of the receptor, resulting overall in a decrease in CYP1A1 mRNA caused by other, more potent AhR ligands. The induction of CYP1A1 mRNA and the inhibition of CYP1A1 EROD activity by galangin may indicate that it is a natural substrate of this metabolic pathway in MCF-7 cells, but this was not examined in the present study.

Known ligands of the AhR are, for the most part, man-made chemicals; natural ligands have been postulated but, with the exception of indolo[2,3]-carbazole (Jellinck et al, 1993), remain unidentified. We have hypothesized elsewhere (Ciolino et al, 1998) that dietary polyphenolic compounds are natural ligands of the AhR and galangin appears to be such a compound. These experiments demonstrate that galangin inhibits carcinogen activation in MCF-7 cells at two levels: through direct inhibition of CYP1A1 enzyme activity and by inhibiting the increase in CYP1Al transcription caused by AhR ligands. There is no study, to our knowledge, on the chemopreventive effect of galangin in animal models of carcinogenesis. Based on our data, galangin may be a promising candidate for in vivo chemoprevention studies. 


\section{ACKNOWLEDGEMENTS}

The authors wish to thank Dr Thomas Barlow and Dr Anthony Dipple for their help in measuring DMBA metabolism, and Dr Robert Clarke for his critical reading of this manuscript.

\section{REFERENCES}

Bradford M (1976) A rapid and sensitive method for the quantitation of microgram quantities of protein utilizing the principle of protein-dye binding. Anal Biochem 72: 248-254

Buening M, Chan R, Huang M, Fortner J, Wood A and Conney A (1981) Activation and inhibition of benzo $(a)$ pyrene and aflatoxin B1 metabolism in human liver microsomes by naturally occurring flavonoids. Cancer Res 41: 67-72

Canivenc-Lavier M, Vernevaut M, Totis M, Siess M, Magdalou J and Suschetet M (1996) Comparative effects of flavonoids and model inducers on drug metabolizing enzymes in rat liver. Toxicology 114: 19-27

Christou M, Savas U, Spink D, Gierthy J and Jefcoate C (1994) Co-expression of human CYP1A1 and a human analog of cytochrome $\mathrm{P}_{450}$-EF in response to 2,3,7,8-cells. tetrachlorodibenzo- $p$-dioxin in the human mammary carcinomaderived MCF-7 cell. Carcinogenesis 15: 725-732

Ciolino H, Daschner P, Wang T and Yeh G (1998) The effect of curcumin on the aryl hydrocarbon receptor and cytochrome $\mathrm{P}_{450} 1 \mathrm{~A} 1$ in MCF-7 human breast carcinoma cells. Biochem Pharmacol 56: 197-206

Critchfield J, Welsh C, Phang J and Yeh G (1994) Modulation of adriamycin accumulation and efflux by flavonoids in HCT-15 colon cells. Activation of Pglycoprotein as a putative mechanism. Biochem Pharmacol 48: 1437-1445

Csokay B, Prajda N, Weber G and Olah E (1997) Molecular mechanisms in the antiproliferative action of quercetin. Life Sci $\mathbf{6 0}: 2157-2163$

Dipple A (1995) DNA adducts of chemical carcinogens. Carcinogenesis 16: $437-441$

Dohr O, Vogel C and Abel J (1995) Different response of 2,3,7,8-tetrachlorodibenzop-dioxin (TCDD)-sensitive genes in human breast cancer MCF-7 and MDAMB 231 cells. Arch Biochem Biophys 321: 405-412

Eaton E, Walle U, Lewis A, Hudson T, Wilson A and Walle T (1996) Flavonoids, potent inhibitors of the human P-form phenolsulfotransferase. Potential role in drug metabolism and chemoprevention. Drug Metab Dispo 24: 232-237

Formica J and Regelson W (1995) Review of the biology of quercetin and related bioflavonoids. Food Chem Toxicol 33: 1061-1080

Hollman P and Katan M (1997) Absorption, metabolism and health effects of dietary flavonoids in man. Biomed Pharmacother 51: 305-310

Hollman P and Katan M (1998) Bioavailability and health effects of dietary flavonols in man. Arch Toxicol Suppl 20: 237-248

Hollman P, van Trijp J, Mengelers M, de Vries J and Katan M (1997) Bioavailability of the dietary antioxidant flavonol quercetin in man. Cancer Lett 114: 139-140

Huggins C, Grand L and Brillantes F (1961) Mammary cancer induced by a single feeding of polynuclear hydrocarbons, and its suppression. Nature 189: 204-207

Jellinck P, Forkert P, Riddick D, Okey A, Michnovicz J and Bradlow H (1993) Ah receptor binding properties of indole carbinols and induction of hepatic estradiol hydroxylation. Biochem Pharmacol 45: 1129-1136

Kao Y, Zhou C, Sherman M, Laughton C and Chen S (1998) Molecular basis of the inhibition of human aromatase (estrogen synthetase) by flavone and isoflavone phytoestrogens: a site-directed mutagenesis study. Environ Health Perspect 106: $85-92$

Kennedy S and Jones S (1994) Simultaneous measurement of cytochrome $\mathrm{P}_{450} 1 \mathrm{~A}$ catalytic activity and total protein concentration with a fluorescence plate reader. Anal Biochem 222: 217-223

Kono Y, Kobayashi K, Tagawa S, Adachi K, Ueda A, Sawa Y and Shibata H (1997) Antioxidant activity of polyphenolics in diets. Rate constants of reactions of chlorogenic acid and caffeic acid with reactive species of oxygen and nitrogen. Biochim Biophys Acta 1335: 335-342

Kuhnau J (1976) The flavonoids. A class of semi-essential food components: their role in human nutrition. World Rev Nutr Diet 24: 117-191

Lamartiniere C, Moore J, Brown N, Thompson R, Hardin M and Barnes S (1995) Genistein suppresses mammary cancer in rats. Carcinogenesis 16: 2833-2840

Larsen MC, Angus WG, Brake PB, Eltom SE, Sukow KA and Jefcoate CR (1998) Characterization of CYP1B1 and CYP1A1 expression in human mammary epithelial cells: role of the aryl hydrocarbon receptor in polycyclic aromatic hydrocarbon metabolism. Cancer Res 58: 2366-2374

Lubinski J, Flint O and Durham S (1994) In vivo and in vitro studies of rat liver cytochrome $\mathrm{P}_{450}$ induction: II. In vitro induction by phenobarbitol and 3 methylcholanthrene measured in an automated 24-well plate assay for cytochrome $\mathrm{P}_{450}$-dependent activity (pentoxyresorufin- $O$-deethylase and ethoxyresorufin- $O$-deethylase). In Vitro Toxicol 7: 13-23

Manach C, Morand C, Texier O, Favier M, Agullo G, Demigne C, Regerat F and Remsy C (1995) Quercetin metabolites in plasma of rats fed diets containing rutin or quercetin. J Nutr 125: 1911-1922

Miller S, Dykes D and Polesky H (1988) A simple salting out procedure for extracting DNA from human nucleated cells. Nucleic Acids Res 16: 1215

Mirzoeva O and Calder P (1996) The effect of propolis and its components on eicosanoid production during the inflammatory response. Prostaglandins Leukot Essent Fatty Acids 55: 441-449

Moon JY, Lee DW and Park KH (1998) Inhibition of 7-ethoxycoumarin $O$ deethylase activity in rat liver microsomes by naturally occurring flavonoids: structure-activity relationships. Xenobiotica 28 : 117-126

Moore M, Wang X, Lu Y, Wormke M, Craig A, Gerlach J, Burghardt R, Barhoumi R and Safe S (1994) Benzo[a]pyrene-resistant MCF-7 human breast cancer cells. A unique aryl hydrocarbon-nonresponsive clone. J Biol Chem 269: 11751-11759

Morton M, Chan P, Cheng C, Blacklock N, Matos-Ferreira A, Abranches-Monteiro L, Correia R, Lloyd S and Griffiths K (1997) Lignans and isoflavonoids in plasma and prostatic fluid in men: samples from Portugal, Hong Kong, and the United Kingdom. Prostate 32: 122-128

Noda Y, Anzai K, Mori A, Kohno M, Shinmei M and Packer L (1997) Hydroxyl and superoxide anion radical scavenging activities of natural source antioxidants using the computerized JES-FR30 ESR spectrometer system. Biochem Mol Biol Int 42: 35-44

Rosenthal N (1987) Identification of regulatory elements of cloned genes with functional assays. Methods Enzymol 152: 704

Rowlands J and Gustafsson J (1997) Aryl hydrocarbon receptor-mediated signal transduction. Crit Rev Toxicol 27: 109-134

Rubinstein L, Shoemaker R, Paull K, Simon R, Tosin S, Skehan P, Scudiero D, Monks A and Boyd M (1990) Comparison of in vitro anticancer-drug-screening data generated with a tetrazolium assay versus a protein assay against a diverse panel of human tumor cell lines. J Natl Cancer Inst 82: 1113-1118

Shimada T, Gillam EM, Sutter TR, Strickland PT, Guengerich FP and Yamazaki H (1997) Oxidation of xenobiotics by recombinant human cytochrome P450 1B1 Drug Metab Dispos 25: 617-622

Siess M, Leclerc J, Canivenc-Lavier M, Rat P and Suschetet M (1995) Heterogenous effects of natural flavonoids on monooxygenase activities in human and rat liver microsomes. Toxicol Appl Pharmacol 130: 73-78

So F, Guthrie N, Chambers A, Moussa M and Carroll K (1996) Inhibition of human breast cancer cell proliferation and delay of mammary tumorigenesis by flavonoids and citrus juices. Nutr Cancer 26: 167-181

So F, Guthrie N, Chambers A and Carroll K (1997) Inhibition of proliferation of estrogen receptor-positive MCF-7 human breast cancer cells by flavonoids in the presence and absence of excess estrogen. Cancer Lett 112: 127-133

Sogawa K, Fujisawa-Sehara A, Yamane M and Fujii-Kuriyama Y (1986) Location of regulatory elements responsible for drug induction in the rat cytochrome $\mathrm{P}_{450 \mathrm{c}}$ gene. Proc Natl Acad Sci USA 83: 8044-8048

Sousa R and Marletta M (1985) Inhibition of cytochrome $\mathrm{P}_{450}$ activity in rat liver microsomes by the naturally occurring flavonoid, quercetin. Arch Biochem Biophys 240: $345-357$

Steinmetz K and Potter J (1996) Vegetables, fruit, and cancer prevention: a review. J Am Diet Assoc 96: 1027-1039

Tsyrlov IB, Mikhailenko VM and Gelboin HV (1994) Isozyme- and species-specific susceptibility of cDNA-expressed CYP1 $\mathrm{A}_{450}$ s to different flavonoids. Biochim Biophys Acta 1205: 325-335

Verma A, Johnson J, Gould M and Tanner M (1988) Inhibition of 7,12dimethylbenz- $[a]$-anthracene- and $N$-nitrosomethylurea-induced rat mammary cancer by dietary flavonol quercetin. Cancer Res 48: 5754-5758

Wang X, Thomsen J, Santostefano M, Rosengren R, Safe S and Perdew G (1995) Comparative properties of the nuclear aryl hydrocarbon (Ah) receptor complex from several human cell lines. Eur J Pharmacol 293: 191-205

Wattenberg L (1985) Chemoprevention of cancer. Cancer Res 45: 1-8 